\title{
Antimicrobial Effect of Rheum ribes and Tio2 Nps on Bacterial Biofilm in Escherichia Coli
}

\author{
Hind Hussein Obaid ${ }^{1}$, Zainab Zamel Khalaf ${ }^{1}$, Heba Khaleel Tawfeeq ${ }^{2}$, \\ RoaaThaer Sabri ${ }^{1}$ and Zeina Abdul-Qader Abdul-Jabbar ${ }^{1}$ \\ 1. Department of Biology, College of science, University of Baghdad, Baghdad, Iraq \\ 2. Central Environmental Laboratory, College of science, University of Baghdad, Baghdad, Iraq
}

\begin{abstract}
Rheum ribs reported to have used in traditional medicine system, and also used as antimicrobial agent against different species of bacteria. Tio2 NPs one of the most widely material that investigated for killing or inhibition of bacteria. In order that, this research was came to study the effects of antibiofilm $R$. ribs extract and Tio2 on uropathogenic E. coli. Furthermore, study the effect of R. ribs and Tio2 combination by using tissue culture plate method. The results showed that $R$. ribs extract and Tio2 gave inhibition effect against bacterial biofilm in high percentage (60-80\%) and (65-76\%) respectively, the first effect on (E7-E16) and the second (E9E16), but the highly effect observed when mix each one of them with others one in percentage (60-78\%) against 11 bacterial isolates from (E6-E16). From these results we can concluded that the R. ribs extract and Tio2 may act as an antibacterial agents in thefuture.
\end{abstract}

Key words: Rheum ribs, TiO2 NPs, Biofilm, E.coli.

\section{Introduction}

Although most of Escherichia coli strains in the gut of humans and animals are bacterial flora, several are excellent opportunistic pathogens [1]. E. coli extraintestinal infections (urinary tract infections and bloodstream infections) represent a significant public health burden worldwide $[2,3]$. Since the 2000s, antimicrobial resistance among $E$. coli isolates has increased contributing to the complexity in management of such infections [4,5]. Rheum ribes (Rhubarb) belongs to the family of polygonaceae and it one of perennial and stout herbs species that chiefly distributed in the countries of Asia, in the temperate and subtropical world regions. The local name of $R$. ribes is Rewas and it grows in the north of Iraq, Iran, Palestine and Turkey [6]. $R$. ribes was used in traditional medicine system, the thick leaf-stalk of the plant used as a vegetable [7]. Roots as well as the powder of leaf-stalk used to relieve gastric illnesses and many disorders like liver, constipation, uterine, headache, bladder and kidney disorders. Also, it used as aperitif and in bile secretion [8]. As for antimicrobial influence, it was used against many of gram negative microbes such as Pseudomonas aeruginosa, Escherichia coli and Klebsiella pneumonia [9]. Many studies referred to the potential applications of metal oxide nanoparticles in biological systems, therapeutics, diagnostics, surgical devices and antimicrobial uses $[10,11,12,13]$. Hydroxyl radicals and superoxide ions trigger from titanium dioxide nanoparticles (TiO2) when the late exposed to ultraviolet (UV) light, non-lethal level, and this resulted in decompose of organic

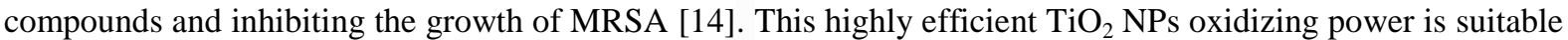
in case of bacteria and other organic substances $[16,17,18]$.The increasing application of drugs has resulted in the resistance of pathogenic microorganisms to existing antimicrobial compounds. Hence, exploring and designing alternative drugs from natural products is necessary to combat microbial infections. Plant-based drugs, which probably evolved as a chemical defense against predation or infection, is perceived to have less or no side effect compared with synthetic antibiotics [18, 19]. Biofilm-forming Escherichia coli strains are responsible for most infections in patients with indwelling bladder catheters [20]. Biofilm-associated bacteria are often hard to eradicate by antibiotics and can tolerate hundred- or thousand fold Higher doses than the corresponding planktonic bacteria [21]. E. coli has also been reported to be able to form intracellular biofilmlike aggregates inside bladder cells, making them hard to reach by both host defense mechanisms and antibiotics [22], sothis study was aimed to investigate the antibiofilm effect of Rhubarb extract and Tio2 NPs against uropathogenic $E$. coli and study the synergistic effect of them against this bacteria.

\subsection{Isolation and identification}

\section{Materials and Methods}

Specimens of urine were collected in sterilized containers, In the laboratory within aseptic conditions, the collected specimens were streaked directly on MacConkey and EMB agar (Himedia/India) for identified uropathogenic E. coli, then incubated for $24 \mathrm{~h}$ at $37^{\circ} \mathrm{C}$. Pink colonies were picked and re cultured on another 
MacConkey and EMB agar. Further identification tests included the morphological characteristics and biochemical tests were carried out depending on [23]. Finally API E20 system was done.

\subsection{Plant}

\subsubsection{Plant collection and preparation of alcoholic extract}

Local markets from Karbalaa and Baghdad were visited to collect Rhizomes of $R$. ribes in October 2013.These markets Authenticated, according to taxonomic method, by Herbarium of Iraqi Health Ministry. As for extraction, $100 \mathrm{gm}$ of $R$. ribes rhizomes needed to prepare $94 \%$ methanol extract by using percolation. Time of extraction was $24 \mathrm{~h}$. Whatman No.1 filter paper used to filtrate the extract. Sterilized by $0.22 \mu$ micro filters [24].

\subsubsection{GC-MS analysis}

Modified method [26] was used for Gas Chromatography - Mass Spectrometry GC-MS analysis based on [25]. Two agilents (6890GC system) and (5973N MSD) were coupled and operating at $70 \mathrm{eV}$, using $200{ }^{\circ} \mathrm{C}$ lit temperature; temperature of ion source was $200^{\circ} \mathrm{C}$; volume of $(1 \mu \mathrm{l})$ used for split injection (50:1 split ratio); Capillary column (Agilent J \& W, USA) with HP-5MS $30 \mathrm{~m}$ x $0.25 \mathrm{~mm}$ ID x $0.25 \mu \mathrm{m}$ film was used; 100 ${ }^{\circ} \mathrm{C} / \mathrm{min}$ oven; $275{ }^{\circ} \mathrm{C}$ for $20 \mathrm{~min}$ at $10{ }^{\circ} \mathrm{C} / \mathrm{min}$; temperature of transfer line: $220^{\circ} \mathrm{C}$. Helium carrier gas; flow rate (constant) $1 \mathrm{ml} / \mathrm{min}$; Agilent GC/MSD ChemStation Version (D.02.00) was used for data acquisition

\subsection{Nanoparticles}

\subsubsection{Preparation of TiO2 NPs suspension}

The preparation was done according to[27],TiO2 NPs $(100 \mathrm{mg})$ was added to sterile D.W (10 ml) and then vigorously shaken. Ultrasound $(40 \mathrm{kHz})$ was focused on the suspending solution for $30 \mathrm{~min}$, after that, suspending solution was autoclaved $\left(121{ }^{\circ} \mathrm{C}\right.$ for $\left.20 \mathrm{~min}\right)$ and left to cool at room temp.

\subsection{Biofilm assay}

Method described by [28] was followed to achieve biofilm formation:

To study the ability of adherence, BHI broth was used to grow (16) E. coli isolates. The broth contained $1 \%$ glucose in 96 - well polystyrene tissue culture plates. Incubation was then done at $37{ }^{\circ} \mathrm{C}$ for $24 \mathrm{~h}$ under aerobic conditions. After got on planktonic cells, the late washed three times with deionized water. In each well, the adhering cells fixed with $200 \mu \mathrm{l}$ absolute methanol for a period of $20 \mathrm{~min}$. The plates left for drying overnight after they emptied. To stain the adhering cells, $200 \mu \mathrm{l}$ of $0.1 \%$ crystal violet was used for $15 \mathrm{~min}$ and the excess stain was then rinsed off. The plates left to air dried overnight after they washed with distilled water. To dissolve the crystal violate, $1 \mathrm{ml}$ of $96 \%$ ethanol was used per well and the absorbance of the plates were then recorded at $490 \mathrm{~nm}$ using a spectrophotometer. The experiment proceeds in triplicates. The wells with sterile TSB recorded as a negative control. The result calculate as in table below.

Table: Classification of bacterial adherence by tissue culture plate method (28)

\begin{tabular}{|l|l|l|}
\hline OD values & Adherence & Biofilm formation \\
\hline$<\mathrm{OD} \mathrm{c}$ & Non & Non \\
\hline $\mathrm{OD}<\mathrm{OD} \leq 2 * \mathrm{ODc}$ & Weakly & Weak \\
\hline $2 * \mathrm{ODc}<\mathrm{ODt} \leq 2 * \mathrm{ODc}$ & Moderately & Moderate \\
\hline $4 \mathrm{ODc}<\mathrm{OD} \mathrm{t}$ & Strong & High \\
\hline
\end{tabular}

\subsection{Detection the antibiofilm activity}

\subsubsection{Detection the antibiofilm activity of $R$. ribes extract against $E$. coli}

The same protocol was used to produce biofilm as mentioned earlier but the different concentrations of plant extract were added with bacterial suspension in the wells as triplicate for each concentration, incubated for 24 $\mathrm{hr}$ at $37^{\circ} \mathrm{C}$, after that all wells were washed, stained, and read O.D at $490 \mathrm{~nm}$.

\subsubsection{Detection the antibiofilm activity of Tio2 against $E$. coli}

The same protocol mentioned in the study the effect of $R$. ribes extract was followed but the different concentrations of Tio2 NPs were added with bacterial suspension in the wells as triplicate for each concentration, incubated for $24 \mathrm{hr}$ at $37^{\circ} \mathrm{C}$, after that all wells were washed, stained, and read O.D at $490 \mathrm{~nm}$.

\subsubsection{Detection the synergistic antibiofilm activity of Tio2 and $R$. ribes extract against $E$. coli}

To investigate the anti-biofilm activity of Tio2NPs in combination with $R$. ribes extract, a TCP assay was also performed. $100 \mu \mathrm{l}$ of the bacterial suspension, at $10 \mathrm{CFU}$, was added to the individual wells of sterile, polystyrene, 96 - well, flat bottomed TCPs after that, Tio2 NPs in combination with Rhubarb extract was added $(50 \mu \mathrm{l}$ from each one of them) with the final concentration being the MIC (the MIC was mentioned in other study under press). The Tio2 NPs were replaced by deionized water in the control well. The TCPs incubated at $37^{\circ} \mathrm{C}$ for a period of $(8)$ hours. The wells were then stained with crystal violate $(0.1 \%)$ after they washed three 
times with distilled water. The stain was rinsed off, resolubilized with ethanol and absorbance was measured at $490 \mathrm{~nm}$. The control was considered to represent $100 \%$ of biofilm formation. The following equation was used to calculate biofilm inhibition percentage [29]:

Biofilm inhibition $(\%)=($ Control OD- Test OD / Control OD $) \times 100$

\subsection{Isolation and identification}

\section{Results and Discussion}

A total no. of 30 urine samples was processed. Out of these samples, 16 isolates were confirmed as uropathogenic E .coli by Gram's staining, culture characterization and biochemical tests. API E20 system was also done as confirmation test.

\subsection{Determination of chemical compounds in $R$. ribs extract GC-MS analyses}

Nine compounds were found in this method. Pattern of fragmentation of compound's peaks compared to that of library compounds. Nine compounds were identified using this method (Table1), (Fig.1). The major components present was 1'H-Cholesta-2,5-dieno[3,2-b]indole, 1'-(phenylmethyl)-(17.094\%).

Table (1): Composition of $R$. ribes rhizomes methanolic extracts.

\begin{tabular}{|c|c|c|c|c|c|c|}
\hline No & Compound & $\begin{array}{l}\text { Retentio } \\
\text { n time } \\
(\mathbf{m i n})\end{array}$ & $\begin{array}{l}\text { Amount } \\
(\%)\end{array}$ & $\begin{array}{l}\text { Chemical } \\
\text { Formula }\end{array}$ & $\begin{array}{l}\text { Molec } \\
\text { ular } \\
\text { weight }\end{array}$ & Synonyms \\
\hline 1 & $\begin{array}{l}\text { Oxalic acid, cyclohexylnonyl } \\
\text { ester }\end{array}$ & 4.102 & $3.772 \%$ & $\mathrm{C}_{17} \mathrm{H}_{30} \mathrm{O}_{4}$ & 298 & no synonyms \\
\hline 2 & $\begin{array}{l}\text { Benzenepropanoic acid, } \alpha- \\
\text { (hydroxyimino)- }\end{array}$ & 4.8 & $2.521 \%$ & $\mathrm{C}_{9} \mathrm{H}_{9} \mathrm{NO}_{3}$ & 179 & $\begin{array}{l}\text { 1.(2Z)-2-(Hydroxyimino)-3- } \\
\text { phenylpropanoic acid \# }\end{array}$ \\
\hline 3 & $\begin{array}{l}\text { 4H-Pyran-4-one 2,3-dihydro- } \\
\text { 3,5-dihydroxy-6-methyl- }\end{array}$ & 4.857 & $2.823 \%$ & $\mathrm{C}_{6} \mathrm{H}_{8} \mathrm{O}_{4}$ & 144 & $\begin{array}{l}\text { 1.3,5- Dihydroxy-6-methyl-2,3- } \\
\text { dihydro-4H-pyran-4-one } \\
\text { 2.2,3- Dihydro-3,5-dihydroxy-6- } \\
\text { methyl-4H-pyran-4-one } \\
\text { 3. Pyranone } \\
\text { 4.2,3-Dihydro-3,5-dihydroxy-6- } \\
\text { methyl-4-pyrone } \\
\text { 5.3-Hydroxy-2,3-dihydromaltol }\end{array}$ \\
\hline 4 & $\begin{array}{l}\text { 1,3-Diazacyclooctane-2- } \\
\text { thione }\end{array}$ & 6.377 & $3.178 \%$ & $\mathrm{C}_{6} \mathrm{H}_{12} \mathrm{~N}_{2} \mathrm{~S}$ & 144 & 1.1,3-Diazocane-2-thione \# \\
\hline 5 & [1,1'-Biphenyl]-4,4'-diamine, & 8.857 & $33.208 \%$ & $\mathrm{C}_{38} \mathrm{H}_{32} \mathrm{~N}_{2}$ & 516 & no synonyms \\
\hline 6 & Bis(diiodoarsino)methane & 13.798 & $14.622 \%$ & $\mathrm{CH}_{2} \mathrm{As}_{2} \mathrm{I}_{4}$ & 672 & no synonyms. \\
\hline 7 & Silane & 15.024 & $14.622 \%$ & $\begin{array}{l}\mathrm{C}_{35} \mathrm{H}_{74} \mathrm{O}_{2} \mathrm{~S} \\
\mathrm{i}\end{array}$ & 554 & no synonyms. \\
\hline 8 & $\begin{array}{l}\text { 1'H-Cholesta-2,5-dieno[3,2- } \\
\text { b]indole, }\end{array}$ & 17.222 & $12.557 \%$ & $: \mathrm{C}_{40} \mathrm{H}_{53} \mathrm{~N}$ & 547 & $\begin{array}{l}\text { 1.7-Benzyl-1-(1,5-dimethylhexyl)- } \\
\text { 12a,14a-dimethyl- } \\
1,2,3,3 \mathrm{a}, 3 \mathrm{~b}, 4,6,7,12,12 \mathrm{a}, 12 \mathrm{~b}, 13,14 \text {, } \\
\text { 14a- } \\
\text { tetradecahydrocyclopenta[5,6]napht } \\
\text { ho[2,1-b]carbazole }\end{array}$ \\
\hline 9 & $\begin{array}{l}\text { 4,6-Bis(4-chloro-3- } \\
\text { (trifluoromethyl)phenoxy)-2- } \\
\text { pyrimidinol tbdms }\end{array}$ & 20.471 & $7.237 \%$ & $\begin{array}{l}\mathrm{C}_{24} \mathrm{H}_{22} \mathrm{Cl}_{2} \\
\mathrm{~F}_{6} \mathrm{~N}_{2} \mathrm{O}_{3} \mathrm{Si}\end{array}$ & 598 & 1.Cl-1077 tbdms \\
\hline
\end{tabular}

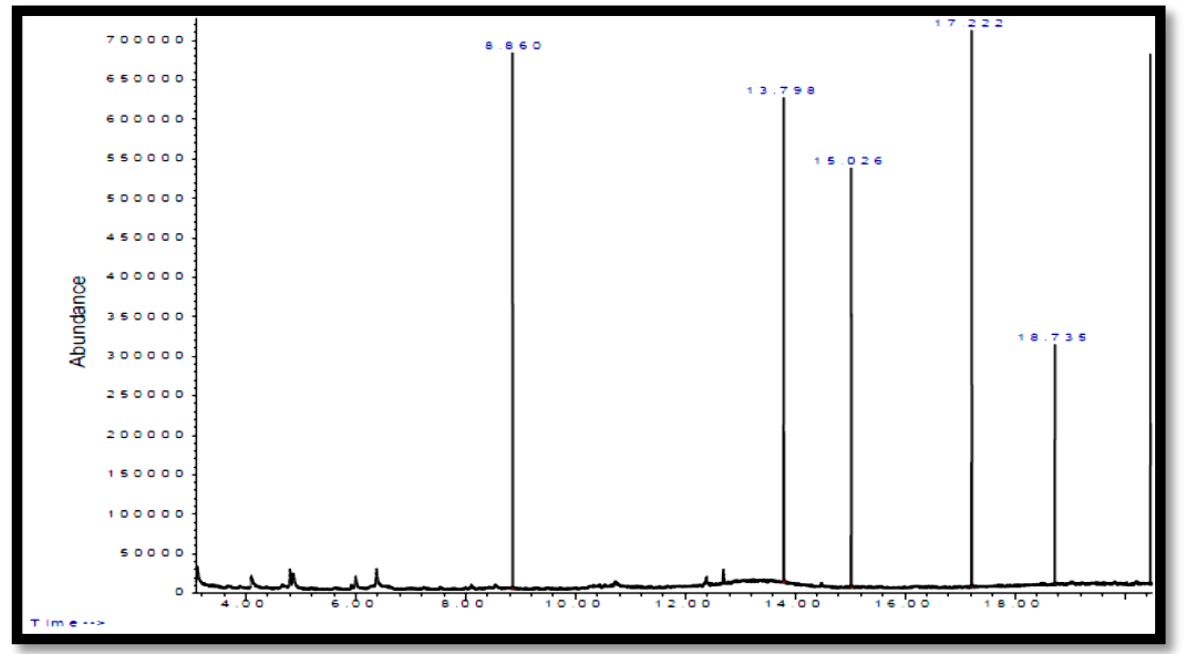

Figure (1): Chromatogram of $R$. ribes rhizomes methanolic extracts by GC-MS. 
The method of GC - MS was given nine compounds. There are a pharmaceutical uses of theses determined compounds. As for oxalic acid, the element in Human blood which it essential for immune system in conditions of many diseases such as, bacterial, viral, cancer and vascular conditions. And when level of oxalic acid drops below its normal range this can be causes reduce immune system efficiency in fighting of many diseases [30]. Also, Bis-(diiodarsino) methane compound have important applications particularly in induce apoptosis of human cancer cells and equalize of abnormal cell growth in cervical dysplasia [31].

\subsection{Biofilm assay}

The results of present study showed that 16 bacterial isolates (93.75\%) gave strong biofilm, while only one isolates $(6.25 \%)$ gave moderate biofilm, that's mean all uropathogenic E. coli in this study were biofilm producers.(see table (2)).

The biofilm production by microtitre plate assay has been performed for numerous bacteria including E. coli [32].

The differences in biofilm thickness resulted from different reasons such as differences in isolates capacity to form biofilm. Perhaps, the primary number of cells that succeeded in adherence and the differences of quality and quantity of auto inducers (quorum sensing signaling molecules) that produced from each isolate play an essential role [33, 34].

The prevalence and detection of biofilm producers have been showed to be dependent upon various factors such as the method, media and incubation period used [35]. In the previous study such as Mohamed et al.[36], he was found that biofilm producing isolates in percentage $(53.0 \%)$ who used

Luria broth incubated for $18 \mathrm{~h}$ and fixed the bacteria with Bouin fixative prior to the rinsing step with phosphate buffered saline (PBS) and Merendez-arancibiaet al. [37] (78\%) who used minimal glucose medium (M63) and incubated for $24 \mathrm{~h}$.

Table (2): Biofilm producing by $E$. coli before treatment, usingmicrotiter plate assay

\begin{tabular}{|l|l|l|l|l|l|l|l|l|}
\hline Isolates & E1 & E2 & E3 & E4 & E5 & E6 & E7 & E8 \\
\hline O.D & $\mathbf{0 . 2 3 1}$ & $\mathbf{0 . 2 7 7}$ & $\mathbf{0 . 2 7 3}$ & $\mathbf{0 . 2 5 2}$ & $\mathbf{0 . 2 8 1}$ & $\mathbf{0 . 2 8 2}$ & $\mathbf{0 . 3 2 8}$ & $\mathbf{0 . 3 6 5}$ \\
\hline Biofilm producing & Moderate & Strong & Strong & Strong & Strong & Strong & Strong & Strong \\
\hline Isolates & E9 & E10 & E11 & E12 & E13 & E14 & $\mathbf{1 5}$ & $\mathbf{1 6}$ \\
\hline O.D & $\mathbf{0 . 3 3 5}$ & $\mathbf{0 . 2 8 6}$ & $\mathbf{0 . 2 9 9}$ & $\mathbf{0 . 3 3 9}$ & $\mathbf{0 . 2 8 2}$ & $\mathbf{0 . 2 7 9}$ & $\mathbf{0 . 2 8 7}$ & $\mathbf{0 . 2 6 2}$ \\
\hline Biofilm producing & Strong & Strong & Strong & Strong & Strong & Strong & Strong & Strong \\
\hline
\end{tabular}

Other findings by[38] who found a rate of $67.5 \%$ and[39] who found a rate of $92.0 \%$, which shows that there is an increased prevalence of biofilm formation by uropathogenic $E$. coli and females are in most cases at higher risks of acquiring $E$. coli induced UTIs.

\subsection{Detection the antibiofilm activity}

\subsubsection{Detection the antibiofilm activity of $R$. ribes methanolic extract}

Rhubarb extract gave antimicrobial effect against Planktonic form of uropathogenic E. coli in all its concentrations, these results reported in other research [40]. There are little studies about the effect of Rhubarb extract on bacterial biofilm, while several studies conducted on its effect against bacteria in a planktonic form. The present research interested in study of effect of this extract on uropathogenic E. coli biofilm, the results indicated that Rhubarb extract was effective against all bacterial isolates and the percentage of effectiveness was higher than from these that appeared by Tio2 NPs, the higher effect against bacterial isolates (E7- E16), in percentage of inhibition $(60 \%-80 \%)$, while lower effect on isolates (E1- E6) in percentage (32\%- 51\%) as mentioned in table (3). Abdulla, K.K. [41] in your study showed that the R. ribes ethanol and aqueous extracts exhibit a broad spectrum of activity against E. coli, S. aureus, P. aeruginosa and P. mirabilis. The antibacterial effects of rhubarb are believed to have been caused by its inhibition of enzymes in the mitochondrial electron +transport system [42].

Table (3): The antibiofilm effect of Rhubarb R. ribes methanolic extract against E.coli

\begin{tabular}{|l|l|l|l|l|l|l|l|l|}
\hline Isolates & E1 & E2 & E3 & E4 & E5 & E6 & E7 & E8 \\
\hline O.D & $\mathbf{0 . 1 3 2}$ & $\mathbf{0 . 1 5 2}$ & $\mathbf{0 . 1 3 5}$ & $\mathbf{0 . 1 7 2}$ & $\mathbf{0 . 1 4 4}$ & $\mathbf{0 . 1 4 6}$ & $\mathbf{0 . 0 9 3}$ & $\mathbf{0 . 1 4 5}$ \\
\hline $\begin{array}{l}\text { Percentage of } \\
\text { inhibition }\end{array}$ & $\mathbf{4 4 \%}$ & $\mathbf{4 5 \%}$ & $\mathbf{5 1 \%}$ & $\mathbf{3 2 \%}$ & $\mathbf{4 9 \%}$ & $\mathbf{4 8 \%}$ & $\mathbf{7 2 \%}$ & $\mathbf{7 2 \%}$ \\
\hline Isolates & $\mathrm{E} \%$ & $\mathrm{E} 10$ & $\mathrm{E} 11$ & $\mathrm{E} 12$ & $\mathrm{E} 13$ & $\mathbf{E 1 4}$ & $\mathbf{1 5}$ & $\mathbf{1 6}$ \\
\hline O.D & $\mathbf{0 . 1 0 1}$ & $\mathbf{0 . 0 6}$ & $\mathbf{0 . 0 7 3}$ & $\mathbf{0 . 0 7 0}$ & $\mathbf{0 . 0 7 9}$ & $\mathbf{0 . 0 7 9}$ & $\mathbf{0 . 0 7 1}$ & $\mathbf{0 . 0 6 1}$ \\
\hline $\begin{array}{l}\text { Percentage } \\
\text { inhibition }\end{array}$ & $\mathbf{6 0 \%}$ & $\mathbf{7 0 \%}$ & $\mathbf{7 6 \%}$ & $\mathbf{8 0 \%}$ & $\mathbf{7 2 \%}$ & $\mathbf{7 2 \%}$ & $\mathbf{7 5 \%}$ & $\mathbf{7 7 \%}$ \\
\hline
\end{tabular}




\subsubsection{Detection the antibiofilm activity of TiO2 NPs}

Well diffusion method by other study [40] was used to investigate the antimicrobial activity of $\mathrm{TiO} 2$ NPs against uropathogenic E. coli. photocatalytic antimicrobial activity of $\mathrm{TiO} 2 \mathrm{NPs}$ was the most studied among various NPs [43]. In a study by Roy et al. [44], they suggested that the TiO2 NPs alone was unable to act as antibacterial, But when it combined with antibiotics they will exhibit antimicrobial activity. But here $\mathrm{TiO} 2$ NPs without any type of combination was able to inhibit uropathogenicE.coli. The results of present study revealed that Tio2 NPs were affected against all bacterial isolates but highly effect against isolates from (E9 E16) in the percentage of inhibition (65-76\%), as show in table (4). There are also studies on bactericidal activity of nitrogen-doped metal oxide nano catalysts on E. coli biofilms and on the photocatalytic oxidation of biofilm components on TiO2- coated surfaces [45]. In conclusion, the use of $\mathrm{TiO} 2$ photocatalysts as alternative means of self-disinfecting contaminated surfaces by further development may provide potent disinfecting solutions for prevention of biofilm formation. $\mathrm{TiO} 2$ photo catalysts can be used as effective biofilm disinfectant in food processing industries [46, 47]. Suspensions containing TiO2 are effective at killing Escherichia coli. This has led to the development of photo catalytic methods for the killing of bacteria and viruses using $\mathrm{TiO} 2$ in aqueous media $[48,49]$.

Table (4): The antibiofilm effect of Tio2 against E.coli

\begin{tabular}{|c|c|c|c|c|c|c|c|c|}
\hline Isolates & E1 & E2 & E3 & E4 & E5 & E6 & E7 & E8 \\
\hline O.D & 0.179 & 0.173 & 0.138 & 0.144 & 0.14 & 0.121 & 0.127 & 0.126 \\
\hline $\begin{array}{l}\text { Percentage of } \\
\text { inhibition }\end{array}$ & $23 \%$ & $38 \%$ & $\mathbf{5 0 \%}$ & $43 \%$ & $50 \%$ & $57 \%$ & $61 \%$ & $61 \%$ \\
\hline Isolates & E9 & E10 & E11 & E12 & E13 & E14 & 15 & 16 \\
\hline O.D & 0.082 & 0.066 & 0.076 & 0.092 & 0.079 & 0.083 & 0.083 & 0.080 \\
\hline $\begin{array}{l}\text { Percentage of } \\
\text { inhibition }\end{array}$ & $65 \%$ & $76 \%$ & $76 \%$ & $73 \%$ & $72 \%$ & $70 \%$ & $71 \%$ & $69 \%$ \\
\hline
\end{tabular}

3.4.3 synergiticantibiofilm activity of $\boldsymbol{R}$. ribes methanolic extract and Tio2 NPs against E.coli In other experiment, study the combination effect of Rhubarb extract and Tio2 was done, the results showed that the antibiofilm effects byRheum ribs and Tio2 together were better than from use each one of them only. All bacteril biofilm was inhibited in percentage from (45\%- 78\%), the highly effects against isolates (E6- E16) with percentage (60- 78), wheares lower effects against isolates (E1- E5), in percentage of inhibition (45-59\%), see table (5).

Table (5): synergiticantibiofilm activity of $R$. ribesmethanolic extract and Tio2 NPs against E.coli

\begin{tabular}{|c|c|c|c|c|c|c|c|c|}
\hline Isolates & E1 & E2 & $\mathbf{E 3}$ & E4 & E5 & E6 & E7 & E8 \\
\hline O.D & 0.166 & 0.152 & 0.111 & 0.116 & 0.138 & 0.105 & 0.13 & 0.142 \\
\hline $\begin{array}{ll}\begin{array}{l}\text { Percentage } \\
\text { inhibition }\end{array} & \text { of } \\
\end{array}$ & $50 \%$ & $45 \%$ & $59 \%$ & $54 \%$ & $51 \%$ & $63 \%$ & $60 \%$ & $60 \%$ \\
\hline Isolates & E9 & E10 & E11 & E12 & E13 & E14 & 15 & 16 \\
\hline O.D & 0.084 & 0.053 & 0.068 & 0.08 & 0.061 & 0.08 & 0.077 & 0.07 \\
\hline $\begin{array}{l}\text { Percentage } \\
\text { inhibition }\end{array}$ & $61 \%$ & $75 \%$ & $77 \%$ & $76 \%$ & $78 \%$ & $71 \%$ & $73 \%$ & $70 \%$ \\
\hline
\end{tabular}

The efficacy of natural products as antimicrobials accompanied by slight or lack of side effect is most likely depends on the compound's structure that interacts with the toxin or pathogen and not with molecules of the host meaning that their effect is specific. This approach has become the rationale for natural drug design studies as a new field of research [50]. When we are made comparision between the three treatment against bacterial biofilm it can be noticed that the effect of R.ribs extract higher than from TiO2 NPs treatment for the bacterial isolates (E1- E8), but is nearly similar against bacterial isolates from (E9- E16). It can be concluded also that synergitic effect of R.ribs with $\mathrm{TiO} 2$ on bacterial isolates gave the best inhibitory effect for biofilm of all isolates at high proportion in compare with other treatments, see table (6).

Table (6): Comparetive between Percentages of inhibition of antibiofilm activity for three treatments against E.coli

\begin{tabular}{|c|c|c|c|c|c|c|c|c|c|}
\hline \multicolumn{2}{|l|}{ Isolates number } & E1 & E2 & E3 & E4 & E5 & E6 & E7 & E8 \\
\hline \multirow{3}{*}{$\begin{array}{l}\text { Percentage } \\
\text { inhibition }\end{array}$} & R. ribes & $44 \%$ & $45 \%$ & $51 \%$ & $32 \%$ & $49 \%$ & $48 \%$ & $72 \%$ & $72 \%$ \\
\hline & Tio2 NPs & $23 \%$ & $38 \%$ & $50 \%$ & $43 \%$ & $50 \%$ & $57 \%$ & $61 \%$ & $61 \%$ \\
\hline & R. ribes+Tio2 NPs & $50 \%$ & $45 \%$ & $59 \%$ & $54 \%$ & $51 \%$ & $63 \%$ & $60 \%$ & $60 \%$ \\
\hline \multicolumn{2}{|l|}{ Isolates number } & E9 & E10 & E11 & E12 & E13 & E14 & 15 & 16 \\
\hline \multirow{3}{*}{$\begin{array}{l}\text { Percentage } \\
\text { inhibition }\end{array}$} & R. ribes & $60 \%$ & $70 \%$ & $76 \%$ & $80 \%$ & $72 \%$ & $72 \%$ & $75 \%$ & $77 \%$ \\
\hline & Tio2 NPs & $65 \%$ & $76 \%$ & $76 \%$ & $73 \%$ & $72 \%$ & $70 \%$ & $71 \%$ & $69 \%$ \\
\hline & R. ribes+Tio2 NPs & $61 \%$ & $75 \%$ & $77 \%$ & $76 \%$ & $78 \%$ & $71 \%$ & $73 \%$ & $70 \%$ \\
\hline
\end{tabular}

DOI: $10.9790 / 3008-1203041420$

www.iosrjournals.org

18 | Page 


\section{Conclusion}

In conclusion, we report a strong synergistic efficiency of R.ribs $\mathrm{TiO} 2$ against $E$. coli biofilm.

\section{References}

[1] A. Frederick.Escherichia coli, It's Prevalence and Antibiotic Resistant in Malaysia:A Mini Review. Microbiol. J.,1, 2011,47-53.

[2] J.R. Johnson, and T.A. Russo.Extraintestinal pathogenic Escherichia coli: "the other bad E. coli". J. Lab. Clin. Med.,139, 2002,155-162.

[3] T.A. Russo, and J.R. Johnson. Medical and economic impact of extraintestinal infections due to Escherichia coli: focus on an increasingly important endemic problem. Microbes Infect,5,2003,449-456.

[4] 4.J.A. Karlowsky, D.J. Hoban, M.R. Decorby,andG.G. Zhanel. Fluoroquinolone-resistant urinary isolates of Escherichia coli from outpatients are frequently multidrug resistant: results from the North American Urinary Tract Infection Collaborative Alliancequinolone Resistance study. Antimicrob. Agents Chemother,50,2006, 2251-2254.

[5] A. Pallettand K. Hand. Complicated urinary tract infections: practical solutions for the treatment of multiresistantGram-negative bacteria. Antimicrob. Chemother, 2010,65

[6] R. Sindhu,A. Kumar, and S. Arora. Investigation Into the anti-ulcer activityofRheum ribesleaves extract. Int J Pharm PharmSci, 2(4),2010, 90-93.

[7] A. Zargari. Medicinal plants (in Persian), vol., $45^{\text {th }}$ ed. Tahran University.1992, pp: 233-241.

[8] H. Haider. Medicinal plants of Iran (in Persian), vol.1, Islamic Culture Press. 1993, pp: 92-95.

[9] B. S. F. Bazzas, M. Khajehkramadin, and H. R. Shokooheizadeh.In vitro antimicrobial activity of Rheum ribes extract obtained from various plant parts against clinical isolates gram negative pathogens.Iranian Journal of Pharmaceutical Research, 4 (2) 2005, 87-91.

[10] J. Sawai. Quantitative evaluation of antibacterial activities of metallic oxide powders $(\mathrm{ZnO}, \mathrm{MgO}$ and $\mathrm{CaO})$ by conductimetric assay. J.Microbiol. Methods, 54, 2003,177-182.

[11] K.A. Laura, Y.L. Delina, and J.J.A. Pedro. Comparative eco-toxicity of nanoscale TiO2, SiO2, and ZnO water suspensions. J. Water Res.,40, 2006, 3527-3532.

[12] K.M. Reddy, F. Kevin, B. Jason, G.W. Denise, H. Cory, and P. Alex.Selective toxicity of zinc oxide nanoparticles to prokaryotic and eukaryotic systems. J. Appl.Phy.Lett., 90, 2007,1-3.

[13] K. Sobha, K. Surendranath, V. Meena, K.T. Jwala, N. Swetha, and K.S.M . Latha. Emerging trends in nanobiotechnology. J.Biotechnol. Mol. Biol. Rev.,5, 2010,1-12.

[14] M..S.A. Shah, M. Nag, T. Kalagara,S. Singh, and S.V. Manorama. Silver on PEG-PU-TiO2 polymer nanocomposite films; an excellent system for antibacterial applications. Chem. Materials,20(7), 2008, 2455-2460.

[15] K. Cho, J. Park, T. Osaka, and S. Park. The study of antimicrobial activity and preservative effects of nanosilver ingredient. Electrochim.Acta.,51, 2005, 956-960.

[16] A.Fujishima,T. N. Rao, and D.A. Tryk. Titanium dioxide photocatalysis. J.Photochem.Photobiol. C: Photochem Rev, 1(1), 2000,121.

[17] Y. Shiraishi,andT. Hirai. Selective organic transformations on titanium oxide-based photocatalysts. J.Photochem.Photobiol. C: Photochem. Rev.,9, 2008, 157-170.

[18] N. Shariff, M.S. Sundarshana, S. Umesh, and H. Prasad. Antimicrobial activity ofRauvolfiatetraphyllaandPhysalis minima leaf and callus extracts. Afr. J. Biotechnology., 5, 2006, 946-950.

[19] M. Hemalatha, B. Arirudran, A. Thenmozhi, and R.U.S. Mahadeva.Antimicrobial Effect of Separate Extract of Acetone, Ethyl Acetate, Methanol and Aqueous from Leaf of Milkweed (Calotropisgigantea L.). Asian J. Pharm. Res., 1 (4) , $2011,102-107$.

[20] J. W. Warren. Catheter-associated urinary tract infections. Int. J.Antimicrob. Agents 17, 2001, $299-303$.

[21] J. W. Costerton, P. S. Stewart, and E. P. Greenberg. Bacterial biofilms: a common cause of persistent infections. Science, 284,1999, 1318-1322..

[22] G. G. Anderson, J. J. Palermo, J. D. Schilling, R. Roth, J. Heuser, andS. J. Hultgren. Intracellular bacterial biofilm-like pods in urinary tract infections. Science 301,2003, 105-107.

[23] B.A. Forbes, D.F. Sahm, and A.S. Weissfeld. (Eds) Enterobacteriaceae. Chapter 25. In: Bailey and Scottís Diagnostic Microbiology. 11th ed. Mosby: St. Louis, 2002, pp:365-77.

[24] M. S.Hanafy, F. M. Saadawy, S. M. N. Milad, andR. M. Ali. Effect of some natural extracts on growth and chemical constituents of Scheffleraarboricolaplants. Journal of Horticultural and Omamental plants, 4(1), 2012, 26-23.

[25] H.Egli.Kjeldahl Guide. BUCHI Labortechnik AG, CH-9230 Flawil, Switzerland, 2008, Pp:58.

[26] R.D. Abdul Jalill, M. A. Kalel, and A. M. Al-Shammari. GC-MS Analysis of Convolvulus arvensis. International Journal of Pharmacy and Therapeutics, 5 (2),2014,122-133.

[27] M.A. Ansari, M.K. Haris, A.K. Aijaz, S. Asfia,and A. Ameer. Synthesis and characterization of the antibacterial potential of ZnO nanoparticles against extended-spectrum b-lactamases-producing E.coli and K. pneumoniaeisolated from a tertiary care hospital of North India. Appl.Microbiol. Biotech.10, 2099,3733-3736.

[28] S.S. Atshan, M.N. Shamsudin, Z. Sekawi, L.T.T. Lung, R.A. Hamat, A. Karunanidhi, A.A. Mateg, E. Ghaznavi-Rad, H. Ghasemzadeh-Moghaddam, J.S. Chong Seng, J.J Nathan, and C. Pei. Prevalence of Adhesion and Regulation of Biofilm-Related Genes in Different Clones of Staphylococcus aureus. J. Biomed. Biotech.,3, 2012, 10-17.

[29] S. Mathur, M. Gutte, D. Paul, and M. Udgire. Study the effect of essential oils on microbial biofilm formation by Klebsiellapneumoniae. Sch. Acad. J. Biosci., 1(3),2013, 76-79.

[30] T. Dahiya,andC. Pundir.In vivo oxalate degradation by liposome encapsulated oxalate oxidase in rat model of hyperoxaluria. Indian J. Med. Res., 137, 2013, 136-141.

[31] M. C. Bell. Efficient rapid synthesis of bis (Indoly) methane using ethyl ammonium nitrate as an ionic liquid. Chem. J., 3 (4), 2000, $114-125$.

[32] C. Almeida, N. F. Azevedo, S. Santos, C. W. Keevil, and M. J. Vieira. Correction: Discriminating Multi-Species Populations in Biofilms with Peptide Nucleic Acid Fluorescence In Situ Hybridization (PNA FISH). PLoS ONE 8(6), 2013,101-371.

[33] R. A. Brady, J. G. Leid, J.H.Calhoun, J. W. Costerton, and M. E.Shirtliff. Osteomyelitis and the role of biofilms in chronic infection. FEMS. Immunol. Med. Microbiol .52, 2008,13-22.

[34] K. E. Beenken, L.N. Mrak, L.M. Griffin, A.K. Zielinska, L.N. Shaw, K. C. Rice, A. R. Horswill, K. W. Bayles, and M. S. Smeltzer. Epistatic relationships between sarA and agr in Staphylococcus aureusbiofilm formation. PLoS One. J. pone.,5, 2010,113. 
[35] T. Mathur, S. Singhal, S. Khan, D.J. Upadhyay, T. Fatma,and A. Rattan. Detection of biofilm formation among the clinical isolates of staphylococci: an evaluation of three different screening methods. Indian J. Med. Microbiol.,24, 2006, $25-29$.

[36] J. A. Mohamed, D. B, Huang, Z. Jiang, H.L. DuPont, J.P. Nataro, J. BelkindGerson, P.C. Okhuysen. Association of putative EnteroaggregativeEscherichia coli virulence genes and biofilm production in isolates from travelers to developing countries. J. Clin. Microbiol.,45, 2007,121-126.

[37] E. Mendez-Arancibia, M. Vargas, S. Soto,J. Ruiz, E.Kahigwa, D.Schellenberg, H. Urassa, J. Gascón, and j. Vila. Prevalence of different virulence factors and biofilm production in enteroaggregative Escherichia coli isolates causing diarrhea in children in Ifakara (Tanzania). Am J Trop Med Hyg,78(6), 2008, 985-989.

[38] M. Sharma, S. Aparna, and U. Chaudhary. Biofilm production in uropathogenicEscherichia coli. Indian J. Pathol. Microbiol., 52,2009, 294- 294

[39] E. Suman, J. Jose, S. Varghese, and M.S. Kotian. Study of biofilm production in Escherichia coli causing urinary tract infection. Indian J. Med. Microbiol., 25, 2007, 305-306.

[40] H.H. Obaid, H.K. Tawfeeq, Z.Z.Khalaf, andZ.S. Shafeeq. Inhibitory effect of Rheum ribes and Tio2 on Escherichia coli. International Journal of Sciences: Basic and Applied Research, 30 (1), 2016, 265-275.

[41] K.K. Abdulla, E.M. Taha,and S. M. Rahim. Phenolic profile, antioxidant, and antibacterial effects of ethanol and aqueous extracts of Rheum ribesL. roots. Der Pharmacia Lettre, 6 (5), 2014, 201-205.

[42] C. Chen, and Q. Chen. Biochemical study of Chinese rhubarb XIX. Localization of inhibition of anthraquinone derivatives on the mitochondrial respiratory chain. ActaPharmaceuticaSinica, 22, 1987,12-18.

[43] S. Gelover, L.A. Gomez, K. Reyes, and M. Teresa. A partia demonstration of water disinfection using TiO2 films and sunlight. Water Res., 40(17), 2006,3274-3278.

[44] A. Roy, P. Ameena, K. Anil, and P.M. Ambika. Effect of nanotitanium dioxide with different antibiotics against methicillinresistant S. aureus. J BiomaterNanobiotech.,1, 2010, 37-41.

[45] T. Matsunga, R. Tomoda, T. Nakajima, N. Nakamura,and T. Kmine. Continuous-sterilization system that uses photosemiconductor powders. Appl.Environ.Microbiol.,54, 1988,1330-1333.

[46] E. J. Wolfrum, J. Huang, D.M. Blake, P.C. Maness, Z. Huang, J. T.Fies,and W. A. Jacoby.Photocatalytic oxidation of bacteria, bacterial and fungal spores, and model biofilm components to carbon dioxide on titanium dioxide-coated surfaces. Environ. Sci. Technol.,36, 2002, 3412-3419.

[47] Y. Liu, J. Li, X.F. Qiu, and C. Burda. Bactericidal activity of nitrogen-doped metal oxide nanocatalysts and the influence of bacterial extracellular polymeric substances (EPS). J. Photochem. Photobiol. A: Chem., 190, 2007, 94-100.

[48] T. Saito, T. Iwase, and T. Morioka. Mode of photocatalytic bactericidal action of powdered semiconductor TiO2 on mutans streptococci. J. of Photochem.andphotobiol., 14, 1992, 369-379.

[49] E.F. Duffy, F. A. Touati, S.C. Kehoe, O.A. McLoughlin, L.W. Gill,W. Gernjak, I. Oller, M.I. Maldonado, S.Malato, J. Cassidy, R.H. Reed, and K.G. McGuigan. Anovel TiO2-assisted solar photocatalytic batch-process disinfection reactor for the treatment of biological and chemical contaminants in domestic drinking water in developing countries. Solar Energy.,77, 2002, 649-655

[50] S. Abachi, S. Lee, and H. P. VasanthaRupasinghe. Molecular Mechanisms of Inhibition of Streptococcus Species by Phytochemicals. Molecules, (21), 2016,1-31. 